\title{
8008008080080800800808008080. 編集後記
}

本号より，会誌編集委員会は新体制となりました。まずは，新体制での最初の号をお届けできることを嬉し く思います。あわせて，これまで長期にわたり編集委員を担当され，第 25 巻第 3 号をもって退任された皆様， 大変お疲れ様でした。この場を借りて, 深く感謝の意を表したいと思います.

さて, 本号の特集は「インテリジェントスマートフォン」ということで 4 件の論文が掲載されています。昨今 のスマートフォンの進化は目覚ましいものがあり, 一年で見違えるようにスペックは向上して高機能になると ともに, 新たなサービスが展開されています。 今後, スマートフォンはより使いやすく, 人の役に立つ存在に なるにはインテリジェント化は欠かせない技術になると思います，将来，更なるインテリジェント化が進むこ とで, ポケットの中に新たなパートナーが存在するようになるかも知れません，その進化に併せて，学会誌の 届け方ひいては学会のあり方も, 学会の名に恥じないようインテリジェントになっていかないといけないと思 います。いずれにしても，時代の変化に合わせて会員の望む情報をタイムリーにお伝えしていけるよう会誌編 集委員の一人として貢献していきたいと思っています。

（会誌編集委員会 第25巻 第 4 号 担当 増田 寛之）

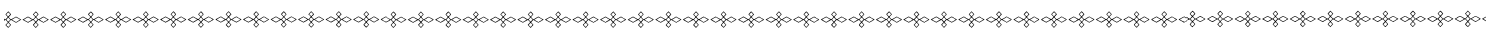

\begin{tabular}{|c|c|c|c|c|c|}
\hline 編集委員長 & 三河 & 正彦（筑波大） & 委 & 員 & 関矢 浩史 (楽天 (株)) \\
\hline 編集副委員長 & 川本 & 一彦（千葉大） & " & & 芳艶（東京工業大） \\
\hline 論文委員長 & 大塚 & 和彦（筑波技術大） & " & & 萩原 将文（慶応義塾大） \\
\hline 論文副委員長 & 岩下 & 志乃（東京工科大） & " & & 豊（高知大） \\
\hline 員 & 井田 & 正明 (大学評価·学位授与機構) & " & & 伴 浩美（福井工業大） \\
\hline " & 稲井日 & 田次郎（日本大） & " & & 増田＼cjkstart寛之（神奈川大） \\
\hline " & 彌冨 & 仁（法政大） & " & & マッキン ケネスジェームス \\
\hline " & 内田 & ゆず（青山学院大） & & & （東京情報大） \\
\hline " & 大竹 & 博（九州工業大） & " & & 宮本 定明（筑波大） \\
\hline " & 岡本 & 一志 (千葉大) & " & & 室伏＼cjkstart俊明（東京工業大） \\
\hline " & 鬼沢 & 武久（筑波大） & " & & 山口＼cjkstart崇志（東京情報大） \\
\hline " & 片上 & 大輔（東京工芸大） & " & & 山崎＼cjkstart洋一（関東学院大） \\
\hline " & 片桐 & 英樹（広島大） & " & & 山下 利之（首都大学東京） \\
\hline " & 菅野 & 直敏（玉川大） & " & & 横川 壽彦（帝京平成大） \\
\hline " & 杉原 & 一臣（福井工業大） & " & & 香（九州工業大） \\
\hline " & 鈴木 & 秀和（東京工芸大） & " & & 吉田 真一 (高知工科大) \\
\hline
\end{tabular}

論文投稿，連載記事などに関する連絡先等の情報は，以下のページをご覧ください.

http://www.j-soft.org/journal/ 